\title{
Rejected Knowledge Reconsidered: Some Methodological Notes on Esotericism and Marginality
}

\author{
Egil Asprem
}

The notion that esotericism is a form of rejected knowledge has come back in style since the publication of Wouter J. Hanegraaff's Esotericism and the Academy in 2012. The association of esotericism with heterodoxy, deviance, opposition, and marginalization is itself old news: it has been a standard trope in insider discourses at least since the nineteenth century, and has also featured in earlier scholarly approaches to the field. In its strictest formulation, the new rejected knowledge model differs from these earlier approaches in important ways. Its central claim is that the historiographical category of "esotericism" emerged from heresiological writings in the seventeenth and eighteenth centuries, which for the first time imagined a diverse set of "heterodoxies" that we now associate with the category as "related currents." However, I will argue that the new rejected knowledge model also comes in an inflated version, in which the distinction between the historiographic concept ("esotericism") and its subject matter becomes blurred. The strict version represents an important contribution to the conceptual history of "esotericism." The inflated version, by contrast, introduces a host of problems that range from how groups and individuals are represented, to how we analyze and explain the data, to how esotericism is legitimized as a relevant field of study in the academy.

The association of esotericism with the rejected, marginal, and repressed has a long history. Modern esoteric insiders have embraced it since the nineteenth century, often sublimating a self-perceived repressed status into the image of a secret tradition of radical opposition to establishment and orthodoxy. Models pitting esotericism against establishment have also been influential in academic takes on the subject. Frances Yates' (1964) presentation of the Renaissance "Hermetic tradition" as an autonomous, progressive counterculture, pointing the way from the "dark middle ages" to an enlightened modernity of science and humanism is an early example, which, presumably because of the counter-canonical view of modernity it provided, was also well received 
outside of academia in the 196os (cf. Hanegraaff, 2001). ${ }^{1}$ James Webb's influential characterization of nineteenth- and twentieth-century occultism as an "underground" of rejected knowledge is another example, this time associating the esoteric (or "occult") with the "irrational," pitting it against a postEnlightenment establishment valorizing "reason." Similarly, the 1970s "sociology of the occult," associated with sociologists such as Edward Tiryakian and Marcello Truzzi, sought to understand the occult explosion of the postwar period in terms of deviance and tension with accepted opinions, devising a number of theoretical perspectives for understanding the significance of such "rejected knowledge" and its associated practices (see e.g. Tiryakian, ed., 1974).

These earlier approaches were questioned and sometimes subjected to polemics when a handful of scholars sought to establish the historical study of esotericism as a valid subfield in the history of religions in the 1990s (see e.g. Faivre and Hanegraaff, 1998). There is, therefore, a certain irony in the fact that, after a short period of trying to define what the study of esotericism is all about in positive terms, most notably through Antoine Faivre's later works (e.g. Faivre, 1994), the negative conceptualization of esotericism as "rejected knowledge" has once again sailed up as a leading approach through the works of Wouter J. Hanegraaff $(2005,2010,2012)$. This appears all the more surprising when we consider that Hanegraaff has been the most vocal critic of the abovementioned approaches, dismissing them either as producing too simplistic narratives (2001), for being too "reductionist" (1995, pp. 119-120), or for being outright "anti-esoteric" (1998, pp. 40-41).

This turn of events becomes less surprising when we recognize that the new rejected knowledge model differs in at least one important respect from the earlier ones. The Yates paradigm held that hermetically inclined Renaissance scholars really were an oppositional counterforce to the scholastic establishment: the worldview of Hermes Trismegistus and the other prisci theologi was pitted against the worldview of Aquinas and late-medieval Aristotelianism. Eventually, at least by the time of the counter-reformation, the establishment stakeholders of the latter would go after the former with inquisitorial methods, culminating in the martyring of one irreverent "Hermeticist," Giordano Bruno, in 16oo. Webb, too, held that the nineteenth-century occult really was "rejected

1 Note, however, that Yates never talked about "esotericism," nor of "rejected knowledge" explicitly. Her hermetic tradition thesis is included here due to its later status as part of esotericism's research tradition. Similarly, it can be appraised as an early rejected knowledge model due to the portrayal of main protagonists as comprising a more or less consistent progressive "counterculture." 
knowledge;" it was explicitly ridiculed and condemned by polite society, and was moreover organized socially in an oppositional underground that would at times seek to overturn the establishment (with horrid consequences when it temporarily succeeded: Webb saw the rise of the "occult" in the early twentieth century as part of a general growth in political irrationalism associated with the rise of anti-Semitism, Fascism, and National Socialism; Webb, 1974). Finally, at least one of the sociologists of the occult (Truzzi) also took as a given that "the occult" is deviant from the perspective of authorized systems of knowledge, whether in the fields of science, medicine, history, or religion. The task was to analyze how such deviance comes about, who is drawn to it, and what social consequences and functions it might have (see Asprem, forthcoming).

\section{2 A New Narrative: The Strict Version}

What the old models have in common is an emphasis on currents that are in some way marginalized or oppositional in their own immediate context. This is precisely where the new narrative, in its most developed formulation, differs. Its main point is historiographical rather than historical: it concerns itself with how history is written, and the role that the category of esotericism plays within the writing of history — not, as the previous approaches did, with how we should characterize the various individuals, groups, practices, or ideas that might be lumped into the category. The statement that esotericism as a historiographical category emerged as rejected knowledge is, quite simply, a statement about how historians have treated certain historical phenomena (or, rather, ignored them). Hanegraaff's Esotericism in the Academy is an attempt to explain why and how that happened.

To simplify the book's complex argument, it all boils down to a perceived problem with paganism that culminated in the seventeenth- and eighteenth centuries. In the seventeenth century, a series of German-speaking Protestant scholars (most notably Jacob Thomasius and Ehregott Daniel Colberg) started formulating explicit heresiological criteria that would allow the scholar to separate pious doctrines from those tainted by paganism. On the one hand, this led to the exclusion of Platonic and Hermetic aspects of Christianity; on the other, it allowed these scholars to construct a view of a whole range of "related currents" which would include, inter alia, Gnosticism, Hermetism, Neoplatonism, Paracelsism, Rosicrucianism, and Christian theosophy. Then, in the eighteenth century, the early historian of philosophy, Johann Jacob Brucker (1696-1770), would base himself on the heresiologists when devising criteria 
for his project of writing a Historia critica philosophia (1742-1744) - that is to say, a critical history of philosophy that selects only that which is good and excludes all the old follies. The result was two parallel narratives: one of true, and one of false philosophy. The story of false philosophy was, once again, made up of currents that would now be seen as "esotericism."

The core argument in Esotericism and the Academy is that these distinctions constituted the first attempts to see such currents as somehow related to each other. The resulting narratives were adopted wholesale by the philosophes of the Enlightenment period, most notably through the extensive plagiarism of Brucker's work by Diderot, d'Alembert, and the authors of the Encyclopédie. This, then, is the point of origin for the rejection of a wide group of currentswhich, nota bene, were not necessarily marginal, rejected, or particularly "related" currents in their own time-from serious academic consideration.

\section{3}

Return of the "Grand Polemical Narrative": The Inflated Version

In practice, however, the crucial distinction between the metalevel of category formation and the status of individual historical cases has not always been so clearly upheld, giving way to an inflated version of rejected knowledge. The strict model tends to be inflated for two related reasons. On the one hand, the rejection episode featuring Protestant heresiologists and Enlightenment historiographers is (often implicitly) put in a broader explanatory context that is best characterized as structural. On the other, this structural explanatory frame casts members of the esoteric family as always implicitly at odds with, and therefore at least potentially discriminated or repressed by, the "dominant culture." This explanatory framework was most explicitly put forth in the article "Forbidden Knowledge: Anti-Esoteric Polemics and Academic Research" (Hanegraaff, 2005), which framed esotericism as the product of a "Grand Polemical Narrative," "the dynamics of which can be traced all the way back to the beginnings of monotheism" (ibid., p. 226). On this story, esotericism is the product of a several millennia long series of polemical formations (specifically: monotheism vs. idolatry, Christianity vs. Gnosticism, Christianity vs. magic and demon-worship, Protestantism vs. ["pagan"] Roman Catholicism, and the Enlightenment vs. the irrational), each of which produced practices of exclusion, silencing, repression, and even extermination of deviant voices. The Grand Polemical Narrative is presented as a persistent structural injustice at the heart of "Western culture." Moreover, "the academic study of Western esotericism" is provided with an emancipatory mission to counter and correct this structural injustice, since 
it "is clearly the natural enemy of the Grand Polemical Narrative" (2005, p. 248).

It is notable that sweeping references to a Grand Polemical Narrative were excised from the 2012 version of the rejected knowledge model. Nevertheless, the notion of a deep, even hidden structural injustice underlying any particular instance of "rejection" remains very much present in practice, even in post-2012 deployments of the model. For example, in a 2019 explanation of what rejected knowledge entails, the treatment of currents now sorted under "esotericism" is explicitly compared to "the traditional exclusion and marginalisation of women, black people and other people of colour, various alternative or non-dominant genders and sexualities, and the victims of Western colonization worldwide" (Hanegraaff, 2019, p. 149). In fact, the injustices committed against "esotericism" are portrayed as deeper than these obvious cases of structural violence, as we read that "the most fundamental grand narratives of Western culture have been constructed on the very basis of 'Othering' and rejecting precisely everything that is studied under the 'esotericism' label today!" - followed by a list of the same disjunctions mentioned in 2005 (Hanegraaff, 2019, pp. 149-150). That critical scholars have so far failed to realize the operations of this anti-esoteric structure is cast as evidence of just how powerful and hegemonic it is:

the pervasive power of that same Western "anti-esoteric" discourse ... is far more dominant and pervasive than most academics realize. Like those fish who wonder "what the hell is water?," even radical critics of Western hegemonic narratives tend to be unaware that this discourse even exists, let alone how it structures their very own assumptions about acceptable and non-acceptable (rejected or discredited) forms of knowledge or methods of inquiry. In short, esotericism is the blind spot par excellence among those radical theorists who are so eager to deconstruct "Western culture". (ibid., pp. 150-151)

These broader implications of the rejected knowledge model — which not only go far beyond the core argument of Esotericism in the Academy, but are now also frequently couched in ideologically loaded language about "identity politics," "no-platforming," and taking the "red pill" (Hanegraaff, 2019; Hanegraaff, Pasi, and Forshaw, 2019) — are deeply problematic. As I will argue in the following, the inflated rejected knowledge model poses problems both for the practical scholarly task of analyzing and explaining historical sources, and for the continued status and relevance of the field in academia. 
The problems posed by the inflated version for practical research purposes can be listed in five concrete issues:

1) The problem of defining the field;

2) the reinforcement of counter-canonical narratives;

3) the affirmation of insider self-understandings;

4) an undifferentiated view of "rejection processes";

5) a failure to address and explain "elected marginality."

The three first problems have a direct bearing on longstanding discussions in the historical study of esotericism. The final two, while also clearly relevant to historical research, become all the more pressing when we look to social science perspectives and to modern and contemporary esotericism. All of these concerns also point us towards the bigger issue of how the field relates to the rest of academia. The following sections will therefore lead us directly to a concluding discussion on what I see as a credible risk of self-marginalization if we fail to refine our approach to rejection and stigmatization processes and relegate these to one issue among many in the field's battery of research questions.

\section{$5 \quad$ The Problem of Defining an Object of Study}

The main rationale for the rejected knowledge model in its strict formulation is precisely to provide grounds for delimiting an object of study: Esotericism refers to a historically contingent "wastebasket" of currents seen to conflict with "proper" religion, philosophy, and science. Although the argument in Esotericism and the Academy makes clear that what was rejected was not chosen arbitrarily, but was rather grounded in specific epistemological and worldview positions, ${ }^{2}$ giving the rejection process itself the pride of place does leave us with a purely negative definition of the field. This problem was already identified by Marco Pasi (2013), Michael Stausberg (2013), and Olav Hammer (2013) during a book symposium in the journal Religion. For all its contributions to our understanding of how a concept of esotericism took shape historically, Pasi noted, the rejected knowledge model in fact "renounces engaging in a

2 Rooted in a so-called "Platonic Orientalism" —itself a far from clear concept—and elsewhere defined as "cosmotheism" and "gnosis" (see Hanegraaff, 2012, pp. 370-373, 377). For a discussion of this concept, see Liana Saif (2021) and Dylan Burns (2021). 
more 'positive' (in the sense of 'position-taking') theoretical work of etic conceptualization" (Pasi, 2013, p. 210). For that reason, it fails to provide a direction for scholars to operationalize the concept. We lack, as Hammer (2013, p. 249) similarly pointed out, a discussion of "the relationship between a genealogical account of how a term is used, and its potential theoretical use."

Stausberg brought up two related problems. First, as we have seen in a number of quotations in the previous section, the model is often phrased as covering everything that has been rejected by the "Enlightenment establishment." Yet, as Stausberg (2013, p. 223-224) points out, the "esoteric repository was only part of a larger picture and not even its most significant specimen." Ignoring everything else that was marginalized, such as "folk" religion and "popular systems of healing," means overshooting the mark. To Stausberg's list may be added a whole range of other ideas, practices, and even categories of people that were, in various ways and to various extents, "rejected" in this period, from political systems such as monarchism, to scientific theories such as phlogiston theory, to entire groups of people such as women or blacks, whose stigmatization were amplified on the grounds of at least some "enlightened" philosophy and science. ${ }^{3}$ Yet, this has not made women's history, the history of monarchy, or theories of heat essential elements of a study of "esotericism." Put differently, "esotericism" is underdetermined by rejection processes (cf. also Hammer, 2013, p. 248).

Stausberg also made the point that it is not entirely obvious why "antiesoteric" authors like Thomasius, Colberg, and Brucker should be given priority as "defining the field" when, as Hanegraaff's own narrative shows, similar clustering is also found by "pro-esoteric" authors like Gottfried Arnold's Unparteyische Kirchen- und Ketzer-Historie (1699-1700) or even the much earlier Catholic perennialist Agustino Steuco's (1497-1548) De perenni philosophia (1540), both of which, like the heresiologists' works, include much of what we would now consider belonging to "esotericism." In a response, Hanegraaff (2013b, p. 263) has explained that the difference is that these works are based on a theological "theoretical framework" that is utterly ahistorical and therefore unusable today. This however seems to miss the point. We are clearly not looking for a fully-fledged scholarly perspective among our sources that we can simply adopt wholesale (that is not what Hanegraaff does with Colberg or Brucker), but simply for works marking a terminus ante quem for emic understandings of "related currents" that we might today call "esotericism."

3 See e.g. the relevant entries in Diderot and d'Alembert, L'encyclopédie. 
The rejected knowledge model has excavated some important twists and turns in scholarly perception of what we would now call "esotericism," but it dodges the question of how to delimit the field. What is more, since earlier historiographical (or mnemohistorical) models did exist, the insistence on giving the polemical category pride of place appears to be grounded in (pre-)theoretical assumptions. One can only suspect that these assumptions were more explicitly stated in 2005, as the Grand Polemical Narrative. The solution to these problems seems to me fairly simple: we must separate the study of rejection processes (a valuable sub-track in research on "esotericism" and its conceptual history) from the vexed question of how to define and operationalize the concept itself for scholarly research. While I will not engage the definition debate here, it suffices to note that a number of different alternatives are on the table, from stipulating new "positive" definitions (including along neo-Faivrean lines), to taking a systematically genealogical approach to esotericism as an "empty signifier" (Bergunder, 2010), or even "fractionating" the concept into more fine-grained analytical concepts that inevitably dissolves "its" status as a separate, semi-autonomous entity, but opens up new vistas of comparison (Asprem, 2016; on the definition debate, see Okropiridze, 2021). The Reinforcement of Counter-Canonical Readings

These considerations lead us to the second problem: the elevation of rejected knowledge as the model for understanding esotericism reinforces the notion of esotericism as a "counter-canonic" current of heterodox thinkers and noble heretics. This is an unintended consequence; the stated goal of the model is, after all, to write "new and better grand narratives" that include and integrate "rejected thinkers" such as Ficino, Lazzarelli, Agrippa, or Paracelsus as "perfectly normal and legitimate" contributors to "Western culture" (Hanegraaff, 2019, pp.151-152). Yet, when these "perfectly normal and legitimate" figures are circumscribed in terms of their assumed heterodox, rejected status, we have, as it seems to me, two problems: on the one hand, the persons of interest of such narratives remain exactly the same "usual suspects" as would previously have been included as members of "the Esoteric Tradition"; on the other, as this inclusion is now justified on the basis of its members having been "rejected" by historical actors cast as representative of "the Establishment," it remains unclear on what - or rather whose - grounds they should now be seen as perfectly legitimate and normal. It must also be noted that simply insisting that figures like the ones mentioned above have been universally rejected by scholars comes with the danger of imposing a language of marginality on sub- 
jects that have already for a long time been treated as "normal." As Hammer (2013, pp. 249-250) has noted about the Swedish scholarly context, intellectual historians in Sweden agreed already in the early twentieth century that Swedenborg's mystical side was part of a wider trend in the Enlightenment period, and works on the role of alchemy in early-modern Swedish history entered the scholarly mainstream, without ridicule or judgment, in the 1940s (see Lamm, 1911; Lamm, 1918-1920; Lindroth, 1943). These advances were made without recourse to a broader category of "esotericism"; insisting on subsuming them under an umbrella of rejected knowledge would represent a step backwards if the aim is to demonstrate the normality of such currents.

Again, all of this is easily solved if we accept only the strict form of the rejected knowledge model, and see the seventeenth- to eighteenth-century rejection process simply as one particular episode of interest in the conceptual history of "esotericism." On those grounds, the "normality and legitimacy" of some members of the category at some times and places could be studied in relation to other voices in their immediate society, that is to say, by analyzing their position within their local systems of privilege and hegemony. The post-Enlightenment view of an influential humanist philosopher such as Marsilio Ficino (1433-1499) under the powerbroker Cosimo de' Medici's patronage as one of the marginal "irrationals" could then simply be explained as an anachronistic projection. More importantly, since normality and legitimacy are never stable terms, our objective can hardly be to demonstrate that all esotericism was always considered "legitimate," but rather to determine when, by whom, and in what contexts, a certain thinker, current, or practice was variously normalized or contested. Pico della Mirandola (1463-1494) is a good case in point: clearly privileged in terms of his social and economic status (hailing from nobility), his goo theses also ended up on the index of the Roman Catholic Church. Regimes of power are rarely singular, and the same goes for normativity.

These complexities get lost if "rejected knowledge" is made the defining characteristic of the category that organizes our study, and anti-paganism presumed as a persistent hegemonic structure in all periods of "Western culture." Against the backdrop of such invisible structures, even the esotericism of privileged elites, whether we think of the multitudes of alchemists and magicians at the court of emperor Rudolph II in Prague in the seventeenth century, the magical experiments at the court of king Gustav III in Stockholm in the late 170os, or even the mass-marketized esotericism of multi-billion industries such as the contemporary "wellness sector" (Crockford, 2021), can, despite being obviously favored with power, be cast as implicitly "marginalized." 
The above issue is intimately connected with a third problem, namely the risk of reproducing and propping up contemporary esotericist self-understandings that do not necessarily have much to do with reality. The rhetoric of an oppressive establishment pitted against esoteric underdogs has been central to esotericism ever since the term first started to be used as a self-designation among nineteenth-century occultists (cf. Strube, 2017a). A typical characteristic of this ubiquitous narrative is to portray existing establishments, notably in religion and the sciences, as not only repressive, but also dogmatic and simpleminded, while at the same time casting the esoteric underdog as not only repressed, but also in possession of a supreme knowledge that far outmatches that of the establishment. While "the other" is repressive and also wrong, "the self" is marginalized and also part of a superior, underground elite that will, eventually, win out.

We see versions of this narrative time and again, from Theosophy to Traditionalism to parts of contemporary paganism to the so-called New Age movement and contemporary commercialized spirituality. Wherever it is articulated, it functions to create an oppositional us-them binary that not only validates the esoteric "higher knowledge" of the in-group and grounds it in pseudo-historical myths about repressed noble heretics; it also creates a protective barrier around the esoteric knowledge system by explaining away any contradictions by contemporary knowledge specialists (whether scientists, doctors, or academic historians) as part of a repressive rejection strategy.

It is worth noting here that this narrative structure is also usually present when contemporary esotericists articulate conspiracy theories (see Asprem and Dyrendal, 2015; Asprem and Dyrendal, 2019). Public criticism, conflicting views of the past by professional historians or archaeologists, state regulations on complementary medicine or food supplements, or the failure of a new harmonic age to emerge can be dismissed as the machinations of a conspiracy that seeks to suppress the truth and keep the unenlightened sheeple in the dark (cf. Robertson, 2016, pp. 205-210).

Of course, neither the strict nor the inflated version of the rejected knowledge model holds that what is rejected must also be true. Hanegraaff has been clear to specify that the aim of presenting the rejected as "normal" should be pursued irrespective of whatever one might personally think of its value and veracity (Hanegraaff, 2019, pp. 151-152). Yet, casting the whole field as characterized first and foremost by rejection does reinforce the oppositional establishment vs. underground structure. 
This issue gets more serious when the emic view is turned into a normative project by which the field's very rationale is to emancipate the victims of "the establishment." In fact, I see the rejected knowledge paradigm as engaging in two separate emancipation projects, which mirror the strict and inflated versions of the model. The first is to counter the rejection of esotericism in the academy, that is to say, to make the academic study of esotericism a legitimate pursuit in the eyes of other academics. This is a reasonable pursuit, and one that has by now largely succeeded. A quite separate emancipation project, which does not follow from the first, is to liberate the subject matter from its assumed "rejected status" in society at large.

Whenever the social emancipation agenda enters the picture, the risk of (re)producing simplified, partisan, and even soft conspiratorial explanations for esotericists' perceived plight, increases. We see this tendency when polemically charged simplifications, such as "reductionism," "materialism," and more recently "postmodernism," are adopted to identify "anti-esoteric" scholarship, and the scholarly traditions attached to these labels are implicated in "noplatforming" esotericism from the stage of history (Hanegraaff, 2019, p. 149). Singling out "neo-Marxism" and "the Frankfurt School" as central culprits is another example (e.g. Hanegraaff, 2012, pp. 312-314), which has sometimes been carried out in ways that border on the conspiratorial insider discourses of Traditionalism that see a (Jewish coded) "cultural Marxism" as the enemy of "true" spirituality (for an example, see Hakl, 2012, in an article translated from German by the noted Radical Traditionalist Michael Moynihan). While I doubt that such language reflects genuine beliefs of a nefarious conspiracy trying to suppress esoteric spokespersons, it enters an ambiguous discursive field that certainly affords and emboldens such convictions. All of this has consequences for the field's place within the academy, which I will return to in the conclusion.

\section{An Undifferentiated View of Rejection Processes}

An underlying problem that has been running through the discussion so far is the imprecise usage of rejected knowledge in the inflated sense, which leads to confusions regarding who, when, and for what reasons a certain piece of knowledge assumes the status of "rejected." As we have already seen, this problem is clear enough from a historical point of view, where we need to separate between the actors that we are studying, other actors in their environments, the judgments of the scholar, and general academic "tacit knowledge." The problem, however, gets even more pressing when we look at how assumedly 
"rejected knowledge" is negotiated in the modern and contemporary periods, after the processes covered by the strict model had taken place.

First of all, we must recognize that there is more than one way in which some piece of knowledge can fail to find favor with some establishment. Knowledge can be directly rejected and polemicized against by authorities (as the strict model has it with regards to an assorted set of religio-philosophical ideas and traditions), but it can also, as Michael Barkun (2002) argues in his discussion of "stigmatized knowledge," be superseded, ignored, or simply forgotten. In fact, a lot of what scholars might categorize as rejected knowledge is better characterized as superseded knowledge: knowledge which used to be authoritatively recognized, but has since lost that status in competition with new knowledge. Alchemy, astrology, and natural magic could all be framed this way. While the processes through which they were superseded can, of course, be fruitfully analyzed in terms of the polemical discourses operating in the early modern period, we miss crucial nuances if we ignore the fact that they were also replaced and instead lump them together with, e.g., "heretical" religious beliefs, as part of one big category of "rejected knowledge."

Other "non-hegemonic" knowledge claims are simply ignored, not taken seriously enough to critique or engage with and thus not explicitly "rejected." This arguably makes up a huge and understudied segment of the field, especially where esotericism intersects with "low-prestige" knowledge, from popular culture to lived religion. Ironically, due to its focus on counter-canonical narratives dominated by white male literati, the field itself continues the tendency of ignoring low-prestige and "peripheral" knowledge. It is illustrative that we do not even have a proper debate yet about, for example, the practices and knowledges of village cunning folk, or the divination services provided by travelling Romani families in Europe since the fifteenth century, as part of esotericism. The case of the Roma is particularly interesting: not only have they played a role in esoteric invented traditions imagining a lineage from Egypt (see e.g. Farley, 2006, pp. 22-26), but they have also been explicitly rejected for doing "sorcery" by some of the very same "establishment" voices cited as inventors of esotericism as rejected knowledge. In fact, Jacob Thomasius wrote a dissertation on "the philosophy of the gypsies" (Dissertatio philosophica de Cingaris, 1652), which became a foundational work of European antiziganism (Saul, 2007, pp. 2-4).

Another way in which the study of "rejected knowledge" should be made more precise is by distinguishing clearly between three things: 1) empirically verifiable campaigns to reject or marginalize some knowledge, 2) subjective perceptions of having been marginalized, and 3) claims about the goals and intentions of those who (allegedly) do the marginalization or rejection. As we 
have already seen, this is necessary because the claim that one's own position is (dogmatically) rejected performs important identity protecting work in esoteric discourses that needs to be analyzed regardless of whether the claim holds empirically.

Even in cases where we are dealing with authorities explicitly countering some knowledge claim it is important for the scholar to ask on what grounds this happens. In the context of contemporary liberal states, there is for example a huge difference between the rejection of something like neopagan religious groups as not being "real religions," and the rejection of homeopathy as not "real medicine." When a Norwegian Asatru group called Det Norske Åsatrosamfunn tried to get official recognition as a religion according to Norwegian law in 1996, the Ministry of Justice intervened to reject the group for not having an official creed, for endorsing the practice of "magic," and for being a threat to "public morals" through alleged "Satanic rituals" (see Asprem, 2008, pp. 57-58). This could with some justification be considered a case of religious suppression based in an old anti-pagan polemic enforced by the state. By contrast, when homeopathy is rejected as not real medicine, it is typically with reference to countless scientific studies failing to find effects beyond placebo, on the one hand, and by pointing out that the mechanisms by which it is claimed by proponents to work ("potentization" through dilutions, the "memory of water") contradict basic, well-established physics and chemistry, on the other (see e.g. Goldacre, 2008; Singh and Ernst, 2008). Yet, proponents of homeopathy have been known to claim that this is in fact suppression of something that does work (and that Big Pharma knows it!). There have even been attempts, most notably in the UK, by proponents of alternative and complementary medicines to silence scientific critique by suing scientists for libel — a fact which shows just how complicated and distributed the dynamics of suppression by using established legal powers really is. ${ }^{4}$

Surprisingly, perhaps, I find that the older literature on the sociology of the occult, dismissed by esotericism scholars in the 199os, had better tools for differentiating between the who, what, when, and why of rejected knowledge than the present model provides. One example suffices to make this point. Marcello Truzzi (1971) has been criticized for viewing "the occult" as "anomalous knowledge," defined in terms of its deviance from various epistemic norms, and thereby, as the criticism goes, creating a concept that is normative, ahistorical, and anti-esoteric (see Hanegraaff, 1995, for the first formulation of this criticism). This criticism ignores the methodological imperatives

4 See e.g. The Guardian, April 1, 2010. 
that most occupied Truzzi. In fact, he developed an intricate framework for studying how various types of "anomalies" are produced and perceived. One of these, which he calls "theoretical anomalies," are indeed defined in relation to some scientific discipline, but as Truzzi wrote, they "appear unusual only to one with special knowledge or training." In other words, the very practice of singling out deviations from a particular scientific system is entirely dependent on, and relative to, the existence of some expert system. In addition, Truzzi stressed the importance of thorough historicization. Researchers must ask "who is labelling the beliefs as occult [i.e. anomalous], where the labelling is being done (the social context), and at what time the designation is made (the historical period)" (Truzzi, 1971, 637). That the status of a particular piece of knowledge is not fixed, but constantly negotiated by situated social actors was, in fact, a central tenet in the sociology of the occult's research program. ${ }^{5}$

\section{$9 \quad$ Elected Marginality: Heterodoxy as Hegemonic Value}

One final and crucial aspect that the rejected knowledge model tends to overlook is this: to the extent that associating oneself with esotericism leads to a degree of marginalization, the marginality tends to be elected rather than imposed. While we lack systematic studies on how people are socialized into esoteric movements, the anecdotal view is that very few are born into esotericism. Much more commonly, involvement in esoteric currents results from active seekership in what Colin Campbell (1972) calls the "cultic milieu," characterized precisely by circulation of more or less "deviant," non- or counterhegemonic ideas and practices. The elected nature of esoteric involvement underscores just how unwise it is to compare any resulting marginality with the "traditional exclusion" (Hanegraaff, 2019, p. 149) of less mobile identities, such as socio-economic class, gender, sexual orientation, or ethnicity. An otherwise well-positioned, middle class person choosing to adhere to rejected knowledge is a different thing altogether from being marginalized for who you are. But it also points to an important set of research questions that are not really being asked by scholars of esotericism: what motivates involvement in rejected knowledge? Is the associated marginality simply a liability, to be balanced against perceived benefits, or may it in fact be seen as an asset?

5 For a thorough reassessment of the sociology of the occult, see Asprem, forthcoming. 
Again, we lack studies of what motivates social actors drawn to esoteric movements and what they think about esotericism's presumed rejected status. But we do know that taking a heterodox stance can in many circumstances be highly desirable. Being "anti-Establishment" is a winning recipe in populist politics as much as in a business culture that rewards norm-breaking startups that "disrupt" the system. At a time when "political correctness" has become perhaps the most widely used political boo-word, aligning with heterodox, assumedly "rejected" or marginal ideas can take on the function of virtue signaling: "I don't go with the consensus!" In everyday contexts, this may just as well lead to social rewards as to stigma, depending on the circles in which one moves and the audiences from which one seeks attention. In contexts such as the cultic milieu, it is far from obvious that actors would want to seek normalization or mainstream acceptance. The opposite may well be true: mainstreaming is often countered by the "amplification of deviance," doubling down on radical expressions in ways that reestablish one's transgressive subcultural capital (Asprem, forthcoming; cf. Kahn-Harris, 20o6). Historically, we find precisely this sort of self-conscious embrace of the "heretical," standing proudly against the corrupt alliance of church and state, when the notion of "occultism" emerged in French socialist circles in the early nineteenth century (Strube, 2017a, 2017b).

We also know that, at least since the 196os, the oppositional and deviant sells. As Thomas Frank noted in his work on "hip consumerism," "[c]ommercial fantasies of rebellion, liberation, and outright 'revolution' against the stultifying demands of mass society are commonplace almost to the point of invisibility in advertising, movies, and television programming" (Frank, 1997, p. 4-5). Elected marginality is mainstream, everyday, even commercialized. It is tied to the production of identities that play on tropes such as the underdog, the noble heretic, the authentic non-conformist, or the rebellious freethinker; yet, it plays to thoroughly hegemonic cultural values of individualism, autonomy, and self-dependence.

Against this background, it is not hard to imagine that making rejected knowledge one's own might be attractive to many. It makes the emergence of "popular occulture" (Partridge, 2014) seem entirely unsurprising, and the embrace of the aesthetics of the occult as a language of resistance (e.g., the witch as feminist icon, the labeling of criticism as "witch hunts," or the use of Satan and "dark occultism" as rebellious expression on both the left and the right) quite predictable. Since the logic of such uses are entirely in line with late modern hegemonic notions of individualism and self-expression, it indicates that embracing esoteric rejected knowledge may lead to a sense of empowerment rather than to marginalization in any socially meaningful sense. 
As I hope to have demonstrated, overemphasizing the construction of the category esotericism as rejected knowledge comes at the expense of obscuring the complicated, but much more important questions of how deviance and hegemony are produced, negotiated, and enforced in concrete socio-historical contexts. A sophisticated study of such negotiations must, as I have highlighted above, differentiate between emic and etic explanatory models, elected and enforced marginality, and the benefits and drawbacks of claiming the underdog role. In order to do so, I have argued that esotericism scholarship still has a lot to learn from the social sciences.

There is, however, a danger that the very inflation of the rejected knowledge model is only separating the field further from those approaches that could help refine it. As we have seen, the emancipatory agenda of countering "rejected knowledge" appears to have moved much beyond historicizing how the category was initially shaped in a polemical context, to now also identify an increasing number of contemporary academic approaches, schools, and theoretical traditions as inherently "anti-esoteric." From the early polemic against "reductionist" approaches, recent publications show a worrying fixation with labels such as "neo-Marxism," "Critical Theory," "the Frankfurt school," and "postmodernism," sometimes apotheosized into an attack on "theory" as such (see Strube, 2021, pp. 53-54). "Neo-Marxist" critical theory tends to be implicated directly in a continued rejection of esotericism, often by quoting Adorno's famous “Theses against Occultism” (e.g. Hakl, 2012; cf. Hanegraaff, 2012, pp. 312-314). This, however, tends to come at the expense both of a more nuanced historical understanding of how early critical theory in fact related to "esotericism" (the case of Walter Benjamin's esoteric fascinations being the most obvious counterpoint; cf. Josephson-Storm, 2017, pp. 209-239), and by underplaying the real concerns of "Frankfurt School" critics' diagnoses of modern capitalist society (see e.g. Kilcher, 2019 for a closer reading of Adorno's theses). The problem is that the historical analysis of how certain scholars influenced the conceptual history of esotericism becomes conflated with a polemic against contemporary perspectives on, for example, critical theory. This is particularly unfortunate seeing how important critical theory is for a whole range of approaches that the study of esotericism sorely needs to engage with in order to refine its perspectives, from gender studies and critical race studies to postcolonial and decolonial theory and issues of class (see e.g. Bakker, 2021; Hedenborg White, 2021; Strube, 2021; Villalba, 2021). Excluding those perspectives and dismissing colleagues who work with them can only lead to further theoretical isolation of the field itself. 
In this light, the rejection of "theory" itself by juxtaposition with "history," a peculiarity in some of Hanegraaff's recent work (2012, pp. 366-367; 2013, pp. 266-267), is perhaps the most puzzling of all. The argument is again intimately tied to the emancipatory agenda of the rejected knowledge model: the worry is that coming to, or even selecting, the material with an explicit theoretical framework in mind will end up looking only for specific things with the end result that sources not considered relevant will once again "disappear." The problem with this argument is that there is only one alternative to departing from explicit theorizations, namely, departing from implicit, hidden, or even unrecognized ones. One does not have to be a "radical theorist" (Hanegraaff, 2019, p. 151) to make the point that all scholars, no matter how big the pretention of meeting the world with a "theory-free" open mind, carry with them assumptions about what is relevant and what is not prior to even selecting one's sources. It is a basic epistemological point recognized from the hermeneutics of Gadamer in the humanities to the post-positivism of Popper, Quine, or Kuhn in the natural sciences. The rejected knowledge model, as I have argued, appears to come with heavy layers of unexamined theoretical baggage about what "esotericism" is (what are its sources), which versions of it are relevant in the first place (who speaks for it), and how it ought or ought not to be studied (methods, research questions, analyses). If those unreflective assumptions lead to a suspicion of theoretical reflection in general, and a rejection of certain lines of theorizing in particular, we are at risk of creating an insular field. While the rejected knowledge model had sought to strengthen the legitimacy of the field, it is precisely that wider legitimacy that is at stake if the inflated version of the model takes hold. We should not reject theory to save our sources from oppression; what we need is more sophisticated and systematic theories in order to select and understand them better.

\section{Bibliography}

Asprem, E. (2008) "Heathens up North: Politics, Polemics, and Contemporary Norse Paganism in Norway," The Pomegranate, 10(1), pp. 41-69.

Asprem, E. (2016) "Reverse-Engineering 'Esotericism': How to Prepare a Complex Cultural Concept for the Cognitive Science of Religion," Religion, 46(2), pp. 158-185.

Asprem, E. (forthcoming) "On the Social Organization of Rejected Knowledge: Reassessing the Sociology of the Occult," in Rudbøg, T. and Hedenborg White, M. (eds.) Esotericism and Deviance. Leiden: Brill. 
Asprem, E. and Dyrendal, A. (2015) "Conspirituality Reconsidered: How Surprising and How New is the Confluence of Spirituality and Conspiracy Theory?" Journal of Contemporary Religion, 3o(3), pp. 367-382.

Asprem, E. and Dyrendal, A. (2019), "Close Companions? Esotericism and Conspiray Theories," in Dyrendal, A., Robertson, D., and Asprem, E. (eds.) Handbook of Conspiracy Theory and Contemporary Religion, Leiden: Brill, pp. 207-233.

Bakker, J. (2019) "Hidden Presence: Race and/in the History, Construct, and Study of Western Esotericism," Religion. [Online] DoI 10.1080/o048721X.2019.1642262.

Bakker, J. (2021) "Hidden Presence: Race and the Study of Esotericism," in Asprem, E. and Strube, J. (eds.) New Approaches to the Study of Esotericism. Leiden and Boston: Brill, pp. 147-167.

Barkun, M. (2003) A Culture of Conspiracy: Apocalyptic Visions in Contemporary America. Berkeley: University of California Press.

Bergunder, M. (2010) "What Is Esotericism? Cultural Studies Approaches and the Problems of Definition in Religious Studies," Method \& Theory in the Study of Religion, 22(1), pp. 9-36.

Campbell, C. (1972). "The Cult, the Cultic Milieu, and Secularisation," A Sociological Yearbook of Religion in Britain, 5, pp. 119-136.

Crockford, S. (2021) “What Do Jade Eggs Tell Us About the Category 'Esotericism': Spirituality, Neoliberalism, Secrecy, and Commodities," in Asprem, E. and Strube, J. (eds.) New Approaches to the Study of Esotericism. Leiden and Boston: Brill, pp. 201-216.

Faivre, A. (1994) Access to Western Esotericism. Albany: State University of New York Press.

Faivre, A. and Hanegraaff, W.J. (eds.) (1998) Western Esotericism and the Science of Religion. Leuven: Peeters Publishers.

Farley, H. (2009) A Cultural History of Tarot: From Entertainment to Esotericism. London: I.B. Tauris \& Co.

Frank, T. (1997) Conquest of Cool: Business Culture, Counterculture, and the Rise of Hip Consumerism. Chicago and London: University of Chicago Press.

Goldacre, B. (2008) Bad Science. London: HarperCollins, Fourth Estate.

Hammer, O. (2013) “Deconstructing 'Western Esotericism': On Wouter Hanegraaff's Esotericism and the Academy," Religion, 43(2), pp. 241-251.

Hanegraaff, W.J. (1995) "Empirical Method in the Study of Esotericism," Method and Theory in the Study of Religion, 7(2), pp. 99-129.

Hanegraaff, W.J. (1998) "On the Construction of Esoteric Traditions," in Hanegraaff, W.J. and Faivre, A. (eds.) Western Esotericism and the Science of Religion, Leuven: Peeters Publishing, pp. 11-61.

Hanegraaff, W.J. (2001) "Beyond the Yates Paradigm: The Study of Western Esotericism between Counterculture and New Complexity," Aries, 1(1), pp. 5-37. 
Hanegraaff, W.J. (2005) "Forbidden Knowledge: Anti-Esoteric Polemics and Academic Research," Aries, 5(2), pp. 225-254.

Hanegraaff, W.J. (2010) "The Birth of Esotericism from the Spirit of Protestantism," Aries, 10(2), pp. 197-216.

Hanegraaff, W.J. (2012) Esotericism and the Academy: Rejected Knowledge in Western Culture. Cambridge: Cambridge University Press.

Hedenborg White, M. (2021) "Double Toil and Gender Trouble? Performativity and Femininity in the Cauldron of Esotericism Research," in Asprem, E. and Strube, J. (eds.) New Approaches to the Study of Esotericism. Leiden and Boston: Brill, pp. 182-200.

Kahn-Harris, K. (2006) Extreme Metal: Music and Culture on the Edge. Oxford and New York: Berg Publishers.

Okropiridze, D. (2021) "Interpretation Reconsidered: The Definitional Progression in the Study of Esotericism as a Case in Point for the Varifocal Theory of Interpretation," in Asprem, E. and Strube, J. (eds.) New Approaches to the Study of Esotericism. Leiden and Boston: Brill, pp. 217-240.

Partridge, C. (2014) "Occulture Is Ordinary," in Asprem, E. and Granholm, K. (eds.) Contemporary Esotericism, London: Routledge, pp. 113-133.

Pasi, M. (2013) "The Problems of Rejected Knowledge: Thoughts on Wouter Hanegraaff's Esotericism and the Academy," Religion, 43(2), pp. 201-212.

Robertson, D. (2016) UFOs, Conspiracy Theories, and the New Age. London: Bloomsbury Academic.

Saif, L. (2021) “That I did love the Moor to live with him': Islam in/and the Study of 'Western Esotericism,"' in Asprem, E. and Strube, J. (eds.) New Approaches to the Study of Esotericism. Leiden and Boston: Brill, pp. 67-87.

Saul, N. (2007) Gypsies and Orientalism in German Literature and Anthropology of the Long Nineteenth Century. London: Maney Publishing.

Singh, S. and Ernst, E. (2008) Trick or Treatment: Alternative Medicine on Trial. London: Bantam Press.

Stausberg, M. (2013) "What is it all about? Some reflections on Wouter Hanegraaff's Esotericism and the Academy," Religion, 43(2), pp. 219-230.

Strube, J. (2017a) "Revolution, Illuminismus und Theosophie: Eine Genealogie der 'häretischen' Historiographie des frühen fanzösischen Sozialismus und Kommunismus," Historische Zeitschrift, 304(1), pp. 50-89.

Strube, J. (2017b) "Occultist Identity Formations between Theosophy and Socialism in fin-de-siècle France," Numen, 64, pp. 568-595.

Strube, J. (2021) “Towards the Study of Esotericism Without the 'Western': Esotericism from the Perspective of a Global Religious History," in Asprem, E. and Strube, J. (eds.) New Approaches to the Study of Esotericism. Leiden and Boston: Brill, pp. $45^{-66 .}$ 
The Guardian, 1 April, 2010. "Simon Singh wins libel court battle". uRL: https://www .theguardian.com/uk/2010/apr/o1/simon-singh-wins-libel-court (accessed Nov 14 2019).

Tiryakian, E. (ed.) (1974) On the Margin of the Visible: Sociology, the Esoteric, and the Occult. New York: John Wiley \& Sons.

Truzzi, M. (1971) "Definition and Dimensions of the Occult: Towards a Sociological Perspective," Journal of Popular Culture, (December 1971), pp. 635-646.

Villalba, M. (2021) "The Occult Among the Aborigines of South America? Some Remarks on Race, Coloniality, and the West in the Study of Esotericism," in Asprem, E. and Strube, J. (eds.) New Approaches to the Study of Esotericism. Leiden and Boston: Brill, pp. 88-108.

Webb, J. (1974) The Occult Underground. La Salle: Open Court Publishing. Webb, J. (1976) The Occult Establishment. La Salle: Open Court Publishing.

Yates, F. (1964) Giordano Bruno and the Hermetic Tradition. London: Routledge \& Kegan Paul. 